\title{
Korupsi dalam Perspektif Hukum Islam dan Strategi Pemberantasannya
}

\author{
A. Malthuf Siroj \\ (Pascasarjana IAI Nurul Jadid, Jl. KH Zaini Mun im PaitonProbolinggo, \\ Email:malthuf@gmail.com)
}

\begin{abstract}
Abstrak:
Korupsi merupakan kejahatan luar biasa karena dampak negatifnya yang menyentuh sendi-sendi kehidupan masyarakat luas. Masyarakat yang menjadi korban fenomena tindak korupsi, akan mati secara perlahan-lahan tapi pasti. Kejahatan ini memiliki potensi yang luar biasa untuk menciptakan kesengsaraan, kemelaratan, dan penderitaan orang banyak, terutama kalangan masyarakat bawah yang tidak memiliki akses ekonomi dan mereka dapat memperoleh hak-haknya hanya apabila diberi oleh negara. Korupsi merupakan istilah modern yang tidak ditemukan padanannya dalam kepustakaan hukum Islam. Tapi dengan mengenali unsur-unsur yang terkandung di dalamnya maka istilah ini dalam hukum pidana Islam berhubungan erat dengan pencurian (sariqah), penyuapan (risywah), penggelapan harta (ghulûl), dan perampokan (hirrâbah) dengan sanksi hukum yang berbeda-beda . Korupsi terjadi karena beberapa faktor di antaranya karena pola hidup materialistik konsumtif, sistem politik, kepemimpinan yang lemah, pendidikan agama dan etika yang minim, sistem sosial, dan hukum yang menyuburkan perilaku koruptif. Untuk memberantas korupsi ini dapat dilakukan cara represif melalui jalur penal dan upaya preventif melalui jalur non penal.
\end{abstract}

\section{Kata-kata Kunci:}

Korupsi, Hukum Islam, Pemberantasan, Represif-Penal, Preventif-Non Penal

\begin{abstract}
:
Corruption is an extraordinary crime because of its negative impact on the aspects of community life. People who have been infected by this deadly virus would die slowly but surely. This crime has a tremendous potential to cause misery, destitution and suffering of many people, especially the lower class people who do not have access to the power and economy; those who would have their rights only if they were given by the state. Corruption is a modern term whose synonym could not be found in the Islamic legal literature.
\end{abstract}

al-1hkâm Vol.11 No.2 Desember 2016

DOI 10.19105/al-ihkam.v11i2.1038 
However, by recognizing the elements contained, the term in Islamic criminal law is closely related to theft (sariqah), bribery (risywah), embezzlement of property (ghulûl) and robbery (hirâbah) with different legal sanctions. Corruption occurs because of many factors such as materialistic-consumerism lifestyle, costly political system, weak leadership, lack of religious and ethical education, social and legal systems that support corrupt behaviors. To eradicate corruption, repressive ways can be done through the penal system as well as preventive efforts through non penal system.

\section{Keywords:}

Corruption, Islamic Law, Eradication, Repressive-Penal, Preventive-Non Penal

\section{Pendahuluan}

Banyak ahli menyebut bahwa korupsi adalah kejahatan yang luar biasa (extraordinary crime), mengingat motivasi dan dampak yang diakibatkannya sangat kompleks. Korupsi dapat pula diibaratkan sebagai sebuah penyakit mematikan, yang jika dipelihara sekian lama tanpa ada penanganan serius dari berbagai pihak akan membunuh bangsa itu sendiri secara perlahan-lahan tapi pasti.

Korupsi sangat erat kaitannya dengan harta benda, maka ia dapat pula dikatakan sebagai kejahatan terhadap harta benda (mâliyah). Kejahatan mâliyah ini banyak terjadi pada negara-negara di dunia, termasuk Indonesia. Bahkan China sebagai salah satu negara yang menjadi basis kekuatan ekonomi dunia memperbolehkan perusahaan-perusahaannya untuk menyuap di luar negeri. Di Indonesia sendiri, praktik suap-menyuap, mafia peradilan, pungli, dan perilaku-perilaku koruptif lainnya setiap waktu menghiasi layar kaca televisi dan selalu menjadi pembicaraan yang tidak kunjung selesai.

Sebagai negara hukum, Indonesia tentu telah melakukan berbagai upaya, baik yang bersifat preventif maupun represif. Namun di lapangan, seberat apa pun hukuman yang dijatuhkan negara melalui aparat penegak hukumnya terhadap para pelaku tindak pidana korupsi dan seberapa pun besarnya upaya preventif yang dilakukan, seperti digalakkannya seminar anti-korupsi, pendidikan anti-korupsi, dan sejenisnya, ternyata masih belum cukup untuk meredam dan menghentikan perilaku korup tersebut. Terbukti dengan ditangkapnya ketua DPD Irman Gusman pada 17 September 
2016 oleh Komisi Pemberantasan Korupsi (KPK) terkait dugaan suap impor gula. Kemudian belum sebulan berlalu, tepatnya 11 Oktober 2016, instansi kepolisian juga berhasil menangkap tiga orang aparat sipil negara Kementerian Perhubungan (Kemenhub) yang diduga melakukan pungli. Kedua kasus tersebut hanyalah sebagian kecil dari kasus-kasus korupsi yang ada di Indonesia.

Kendati demikian, perang melawan korupsi sebagai bentuk nahi munkar harus terus ditabuh. Tidak boleh berputus asa, berdiam diri tanpa aksi, apalagi apatis atau malah menjadi bagian dari para pelaku korupsi. Memusuhi korupsi adalah bagian dari jihad. Karena jihad esensinya bukan hanya berkenaan dengan perang fisik pada kelompok di luar Islam, tetapi mencurahkan tenaga dan pikiran dalam melawan korupsi juga dapat dikatakan jihad.

Maka dari itu, dalam artikel singkat ini akan dikaji tentang bagaimana pengertian tindak pidana korupsi dan apa bentuk hukumannya dalam perspektif hukum Islam serta bagaimana pula jihad melawan korupsi dan strategi yang dapat digunakan untuk memberantas perilaku korup yang semakin menjamur di negeri ini.

\section{Definisi Korupsi dalam Hukum Islam}

Dilihat dari sudut terminologi, istilah korupsi berasal dari bahasa latin "corruption", yang berarti kerusakan, kebobrokan atau suatu keadaan dan perbuatan yang busuk. Dalam Bahasa Indonesia, istilah korupsi sering dikaitkan dengan ketidakjujuran atau kecurangan seseorang dalam bidang keuangan. Dengan demikian, melakukan korupsi berarti melakukan kecurangan atau penyimpangan terkait keuangan. ${ }^{1}$

Sementara itu, istilah korupsi dalam Kamus Umum Bahasa Indonesia diartikan sebagai perbuatan yang buruk seperti penggelapan uang, penerimaan uang sogok, dan sebagainya. ${ }^{2}$ Selanjutnya, dalam Peraturan Penguasa Militer Nomor Prt/PM06/1957, istilah korupsi antara lain dimaknai sebagai perbuatanperbuatan yang merugikan keuangan dan perekonomian Negara.

1 Elwi Danil, Korupsi: Konsep, Tindak Pidana, dan Pemberantasannya, (Jakarta: PT. RajaGrafindo Persada), 3.

2 W.J.S. Poerwardarminta, Kamus Umum Bahasa Indonesia, (Jakarta: Balai Pustaka, 1976). 
Dalam perkembangan selanjutnya, hal-hal yang berkaitan dengan korupsi tidak saja meliputi persoalan keuangan, melainkan juga masuk ke ranah gratifikasi dan nepotisme. Gratifikasi umumnya berhubungan dengan benda-benda berharga, termasuk wanita. Sedangkan nepotisme sering dipakai untuk mengutamakan keluarga atau kelompok dalam urusan publik. Kendati berbeda, di antara keduanya terdapat benang merah yang saling berhubungan, yaitu menempatkan kepentingan publik di bawah kepentingan privat, dengan melanggar norma-norma hukum yang berlaku.

Uraian di atas mendeskripsikan bahwa untuk mengenali hakikat dari korupsi ternyata tidak mudah, karena korupsi memiliki batasan yang luas. Maka Syed Hussein Alatas kemudian membeberkan ciri-ciri korupsi dalam usaha mengungkap makna konseptual dari korupsi itu sendiri, yakni:

a. Korupsi senantiasa melibatkan lebih dari satu orang ;

b. Korupsi umumnya melibatkan keserbarahasiaan, kecuali telah begitu merajalela dan mendalam berurat-akar ;

c. Korupsi melibatkan elemen kewajiban dan keuntungan timbal balik;

d. Mereka yang mempraktikkan cara-cara korupsi biasa menyelubungi perbuatannya berlindung di balik pembenaran hukum;

e. Mereka yang terlibat korupsi adalah mereka yang menginginkan keputusan-keputusan yang tegas dan mereka yang mampu mempengaruhi keputusan-keputusan itu;

f. Adanya unsur penipuan dalam setiap tindakan korupsi;

g. Adanya penghianatan dalam setiap bentuk korupsi;

h. Perilaku korupsi melanggar norma-norma tugas dan pertanggungjawaban dalam tatanan masyarakat;

i. Setiap bentuk korupsi melibatkan fungsi ganda yang kontradiktif dari mereka yang korup. ${ }^{3}$

Setelah mengenali ciri-ciri korupsi sebagaimana dikemukakan di atas, lalu bagaimana dengan pengertian korupsi dalam hukum Islam? Untuk memberikan definisi korupsi yang sesuai dengan konteks saat ini dalam perspektif hukum Islam dirasa cukup sulit,

3 Syed Hussein Alatas, Sosiologi Korupsi: Sebuah Penjelajahan dengan Data Kontemporer, (Jakarta: LP3ES, 1981), 12-14. 
karena korupsi merupakan istilah modern yang tidak ditemukan padanannya dalam kepustakaan hukum Islam.

Sebelum memaparkan lebih jauh tentang arti korupsi dalam hukum Islam, perlu diketahui terlebih dahulu tiga unsur utama dari korupsi itu sendiri, yaitu: Pertama, tasharruf, yang bermakna menerima, memberi, dan mengambil sesuatu, dengan tujuan untuk memperkaya diri sendiri, orang lain atau kelompoknya. Kedua, pengkhianatan terhadap amanat kekuasaan. Ketiga, ada kerugian yang harus ditanggung, baik oleh seseorang sebagai individu, masyarakat dan/atau negara. ${ }^{4}$

Dari ketiga hal pokok di atas, secara sederhana dapat dipahami bahwa korupsi merupakan sebuah bentuk tasharruf berupa penghianatan atas kekuasaan sebagai amanah yang diberikan oleh rakyat. Penghianatan tersebut menimbulkan kerugian bagi seseorang, masyarakat dan/atau negara. Islam memberikan stigma tersendiri terhadap orang yang suka berkhianat, yaitu dengan sebutan "munafik". Pada masa Rasulullah dan para sahabat, orang-orang munafik tidak mendapat tempat di ruang publik. Semua orang sepakat saat itu bahwa persaksian orang munafik tidak dapat diterima dalam pemeriksaan di sidang pengadilan; hadits yang diriwayatkan dinilai lemah; bahkan tidak dapat diangkat menjadi pemimpin. Semua itu didasarkan pada satu poin penting dalam kehidupan manusia, yaitu keadilan. Orang munafik tidak bisa memberikan keadilan kepada dirinya sendiri, apalagi kepada khalayak umum.

Dalam hukum Islam, terdapat beberapa istilah yang dapat dinisbatkan terhadap kejahatan korupsi, di antaranya adalah pencurian (sarîah), suap (risywah), penggelapan harta (ghulûl), dan perampokan (hirâbah). Ulama Hanafiyah menyamakan hirâbah dengan sariqah, bahkan hirâbah disebutnya sebagai sariqah kubra (pencurian besar) karena dampak negatifnya bersifat massif, maka hukumannya diperberat dibanding pencurian biasa yang disebutnya sariqah sughrâ (pencurian kecil). ${ }^{5}$

4 Tim Penulis Muhammadiyah dan Nahdlatul Ulama, Koruptor Itu Kafir, (Jakarta: PT Mizan Publika, 2010), 128.

5 Wahbah al-Zuhaylî, al-Fiqh al-Islâmî wa Adillatuh, Juz VI, (Damaskus: Dar al-Fikr, 1984), 128. 


\section{Korelasi antara Korupsi dengan Pencurian}

Di satu sisi, korupsi dan pencurian memiliki kesamaan, yaitu sama-sama memiliki unsur mengambil harta secara tidak sah. Namun di sisi yang berbeda, praktik korupsi jauh lebih kompleks daripada pencurian. Berikut perbedaan keduanya: 6

a. Pencurian pasti dilakukan secara sembunyi-sembunyi, namun korupsi bisa dilakukan secara terang-terangan.

b. Percurian tidak selalu berkaitan dengan amanat pemilik harta kepada si pencuri, sedangkan korupsi pasti berkaitan dengan kepercayaan publik.

c. Harta yang dicuri umumnya adalah harta yang berada di bawah kekuasaan orang lain, sedangkan harta yang dikorupsi pada umumnya berada di bawah kekuasaan si koruptor.

d. Harta yang dicuri bisa jadi harta pribadi maupun harta publik, sedangkan harta yang dikorupsi pasti harta publik.

Sekalipun keduanya memiliki perbedaan-perbedaan yang mendasar, hukum Islam melarang kedua perbuatan tersebut. Allah SWT berfirman dalam Q.S al-Nisa' (4):29

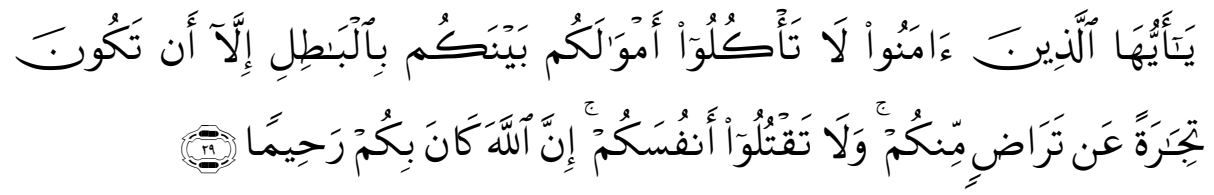

Hai orang-orang yang beriman, janganlah kamu saling memakan harta sesamamu dengan jalan yang batil, kecuali dengan jalan perniagaan yang Berlaku dengan suka sama-suka di antara kamu. dan janganlah kamu membunuh dirimu; Sesungguhnya Allah adalah Maha Penyayang kepadamu.

\section{Korelasi antara Korupsi dengan Suap}

Korupsi juga erat kaitannya dengan suap. Dalam istilah hukum Islam, suap dalam bahasa Indonesia disamakan dengan risywah, walaupun hakikatnya terdapat perbedaan di antara keduanya. Suap secara yuridis salah satunya didefinisikan sebagai suatu perbuatan berupa pemberian atau menjanjikan sesuatu kepada pegawai negeri atau penyelenggara negara dengan maksud supaya pegawai negeri atau penyelenggara tersebut melakukan atau tidak

\footnotetext{
${ }^{6}$ Ibid., 129.
} 
melakukan sesuatu, yang bertentangan dengan kewajibannya. ${ }^{7}$ Dikatakan suap jika perbuatan tersebut dilakukan secara bottom up (dari bawah ke atas) atau dari rakyat ke pejabat atau dari pejabat bawahan ke pejabat atasan.

Sementara dalam hukum Islam istilah risywah diartikan sebagai:

$$
\text { الرشوة ما يحقق الباطل او يبطل الحق } 8
$$

"Suatu perbuatan membenarkan yang salah atau menyalahkan yang benar".

Maka, termasuk dalam kategori risywah manakala dalam suasana kampanye pemilu, baik itu pemilu legislatif (pileg), pemilu presiden (pilpres), pemilu gubernur (pilgub), maupun pemilu bupati (pilbup), para peserta pemilu melakukan "serangan fajar" kepada rakyat untuk memberikan suaranya saat pemilu berlangsung.

Dengan demikian, penelusuran makna konseptual risywah dapat terjadi dari dua arah, baik dari rakyat kepada penguasa untuk mendapatkan kebijakan yang menguntungkan dirinya atau kelompoknya, maupun dari penguasa kepada rakyatnya dengan tujuan untuk mempertahankan dan memperluas kekuasaannya. Sedangkan suap hanya terjadi dari satu arah saja, yaitu dari rakyat kepada penguasa.

\section{Korelasi antara Korupsi dengan Penggelapan Harta}

Dari sisi penggelapan harta, korupsi erat kaitannya dengan istilah "ghulûl" dalam hukum Islam. Konsep ghulûl dalam hukum Islam bermakna "pengkhianatan atas amanah yang seharusnya dijaga". ${ }^{9}$ Sebagaimana firman Allah dalam Q.S Al-Imrân (3): 161

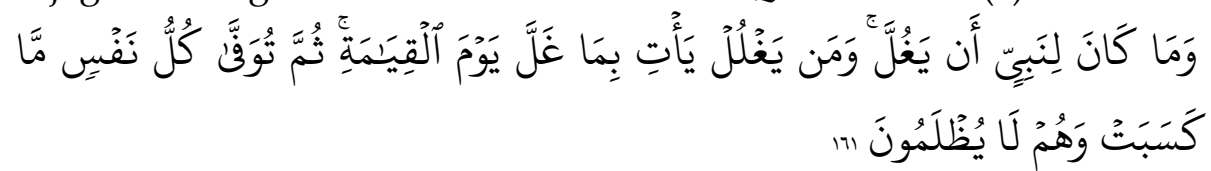

Tidak mungkin seorang nabi berkhianat dalam urusan harta rampasan perang. Barangsiapa yang berkhianat dalam urusan rampasan perang itu, maka pada hari kiamat ia akan datang membawa apa yang dikhianatkannya itu, kemudian tiap-tiap

7 Pasal 5 Undang-Undang No. 20 Tahun 2001 tentang Pemberantasan Tindak Pidana Korupsi

8 Ibn Al-Atsîr, al-Nihâyah fi Gharib al-Hadîts wa al-Atsar..., Jilid II, 226.

9 Tim Penulis Muhammadiyah dan Nahdlatul Ulama, Koruptor..., 18. 
diri akan diberi pembalasan tentang apa yang ia kerjakan dengan (pembalasan) setimpal, sedang mereka tidak dianiaya

Perbuatan khianat dikatakan ghulûl, karena seseorang yang mengambil harta tersebut menyembunyikannya di dalam harta miliknya. Dari sekian banyak perilaku yang mengarah pada perbuatan korupsi, dalam konsep hukum Islam, ghulûl adalah perbuatan yang memiliki karakter paling dekat dengan korupsi. Karena keduanya sama-sama melibatkan penyalahgunaan kekuasaan menyangkut harta publik.

Di samping itu, bila mengacu pada unsur-unsur tindak pidana korupsi, konsep ghulûl memenuhi semua unsur tersebut;

a. Keduanya sama-sama memiliki niat untuk memperkaya diri

b. Keduanya memiliki dampak merugikan orang lain dan kekayaan negara

c. Keduanya terjadi karena adanya penyalahgunaan kekuasaan

d. Keduanya merupakan perbuatan melawan hukum dan merusak sistem hukum dan moral masyarakat.

\section{Korelasi antara Korupsi dengan Perampokan}

Perampokan atau hirâbah merupakan perbuatan yang merusak tatanan kehidupan masyarakat. Begitu pula dengan korupsi, yang merusak segala bidang kehidupan masyarakat, baik di bidang pendidikan, kesehatan, ekonomi dan lain sebagainya.

Hirâbah dan korupsi sama-sama mengancam jiwa dan harta orang banyak serta mengakibatkan kehancuran di berbagai lini kehidupan, misalnya kerusakan lingkungan, mutu pelayanan publik yang rendah, dan penegakan hukum yang lemah. Namun demikian, dampak dari korupsi dinilai masih lebih luas dari pada hirâbah, misalnya;

a. Jiwa yang terancam akibat tindakan korupsi lebih banyak dari hirâbah. Karena hirâbah umumnya hanya mengancam segelintir jiwa. Sedangkan korupsi lebih luas karena jumlah penyelewengan dananya yang besar.

b. Harta yang diambil melalui korupsi lebih besar dari pada hirâbah. Dalam hirâbah, harta yang diambil kecil nominalnya, namun dalam kejahatan korupsi, nominal harta yang diambil dalam jumlah besar hingga ratusan miiyar bahkan triliunan rupiah. 
c. Dampak yang ditimbulkan dari korupsi jauh lebih massif dari pada hirâbah. Menilap anggaran jalan raya, jembatan, bangunan publik seperti gedung pendidikan, kesehatan atau olahraga, berakibat pada kualitas rendah sarana yang dihasilkan. Akibatnya adalah kualitas buruk dalam pelayanan publik.

\section{Faktor Penyebab Tindak Korupsi Menurut Hukum Islam}

Salah satu cendekiawan Muslim, 'Abd al-Rahman Ibn Khaldûn, dikenal sebagai hakim yang jujur dan adil yang berusaha memerangi korupsi dan suap-menyuap di lingkungannya. Namun usahanya gagal dan justru ia dipecat dari jabatannya. Dalam pandangannya, sebab utama merebaknya perilaku korupsi adalah gaya hidup mewah. ${ }^{10}$

Hal itu lebih ditegaskan lagi oleh B. Soedarso sebagaimana dikutip oleh Jur. Andi Hamzah yang menyatakan bahwa salah satu sebab yang sering dihubungkan dengan perilaku korupsi adalah gaji para aparat yang rendah sementara kebutuhan terus meningkat. Namun demikian, beliau menyadari bahwa minimnya gaji bukanlah sebab yang mutlak, realitasnya banyak juga orang berkecukupan yang korupsi. Ada faktor-faktor lain dari luar yang saling mempengaruhi sehingga menimbulkan perilaku korupsi, misalnya kepentingan politis pejabat terkait untuk meraih dan mempertahankan kekuasaannya. ${ }^{11}$

Ansari Yamamah juga berpendapat bahwa bila kecenderungan materialistik dan konsumtif masyarakat serta sistem politik masih berbiaya tinggi, maka hal tersebut memaksa terjadinya permainan uang dan korupsi.12 Kondisi demikian akan dengan sendirinya memaksa para pejabat ketika telah menduduki jabatannya untuk melakukan kejahatan korupsi. Hal senada dikemukakan oleh Nur Syam bahwa seseorang melakukan korupsi karena godaan kekuasaan dan sekaligus kekayaan yang tidak mampu dikendalikan. Saat dorongan untuk menjadi kaya tidak mampu ditahan, sementara

10 Syed Hussein Alatas, Sosiologi..., 8-9.

11 Jur. Andi Hamzah, Pemberantasan Korupsi Melalui Hukum Pidana Nasional dan Internasional, Revisi ke-2, (Jakarta: PT. RajaGrafindo Persada, 2006), 13-14.

12 Tim Penulis Buku Pendidikan Anti-Korupsi, Pendidikan Anti-Korupsi untuk Perguruan Tinggi, (Jakarta: Kementerian Pendidikan dan Kebudayaan RI, 2011), 38. 
akses untuk kaya bisa diperoleh melalui korupsi, maka terjadilah korupsi itu. ${ }^{13}$

Secara terperinci, Syed Hussein Alatas membeberkan sebab terjadinya korupsi sebagai berikut: ketiadaan atau kelemahan kepemimpinan dalam posisi-posisi kunci; kelemahan pengajaranpengajaran agama dan etika; kolonialisme; kurangnya pendidikan; kemiskinan; tiadanya tindak hukuman yang keras; kelangkaan lingkungan yang subur untuk perilaku anti-korupsi; struktur pemerintahan; perubahan radikal; dan keadaan masyarakat. ${ }^{14}$

Selain faktor-faktor yang telah disebutkan di atas, masih terdapat faktor lain yang semakin mengeksiskan perilaku korupsi, yaitu nepotisme. Budaya mengutamakan kepentingan pribadi atau kelompok di atas kepentingan publik, turut serta menguatkan dinasti korupsi, khususnya di dalam tubuh birokrasi. Selama nepotisme hanya didasarkan untuk menguatkan dinasti kekuasaan seseorang, maka jalur korupsi akan terbuka lebar.

\section{Sanksi Bagi Pelaku Tindak Pidana Korupsi Menurut Hukum Islam}

Untuk membuat jera para koruptor, semua orang sepakat jika mereka (pen. koruptor) diberi sanksi hukum yang seberat-beratnya, baik berupa sanksi sosial atau tindakan, maupun sanksi pidana penjara dan denda yang berat. Hal ini mengingat dampak korupsi yang sangat merugikan dan berbahaya untuk kelangsungan hidup suatu bangsa. Akibat korupsi, kemiskinan, kedzaliman, dan ketidakadilan, serta rusaknya moralitas dalam berbagai aspek kehidupan masyarakat mencapai pada puncak kebobrokannya.

Pada dasarnya, semua konsep kejahatan yang berkaitan dengan harta, seperti pencurian (sariqah), penggelapan (ghulûl), penyuapan (risywah), dan perampokan (hirâbah); dapat digunakan untuk menindak para koruptor. Akan tetapi perlu dipertimbangkan hal-hal yang dapat dijadikan dasar untuk menentukan berat dan ringannya sanksi hukuman tersebut. Pada tataran sariqah dan hirâbah, sanksi yang diterapkan dalam hukum Islam adalah hukuman hudîd. Sementara konsep ghulûl dan risywah, keduanya menerapkan sanksi ta'zir.

\footnotetext{
13 Ibid., 39.

14 Syed Hussein Alatas, Sosiologi..., 46.
} 
Hukuman hudûd mengenai pencurian (sariqah) dapat ditemukan landasannya pada Q.S al-Maidah (5): 38 berikut:

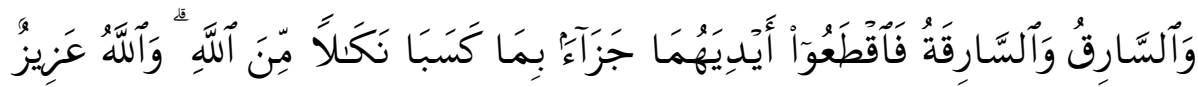

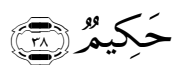

laki-laki yang mencuri dan perempuan yang mencuri, potonglah tangan keduanya (sebagai) pembalasan bagi apa yang mereka kerjakan dan sebagai siksaan dari Allah. dan Allah Maha Perkasa lagi Maha Bijaksana.

Untuk menerapkan hukuman potong tangan (qath' al-yad) terhadap pelaku kejahatan korupsi haruslah disertai kehati-hatian. Mengingat unsur-unsur tindak pidana korupsi yang kompleks, apalagi biasanya ada unsur politisasi terhadap beberapa aturan guna menunjang agar dalam eksekusi kejahatan korupsi berjalan rapi dan terkesan legal.

Sementara untuk hukuman had-nya hirâbah didasarkan pada ayat QS: Al-Maidah (5): 33 berikut:

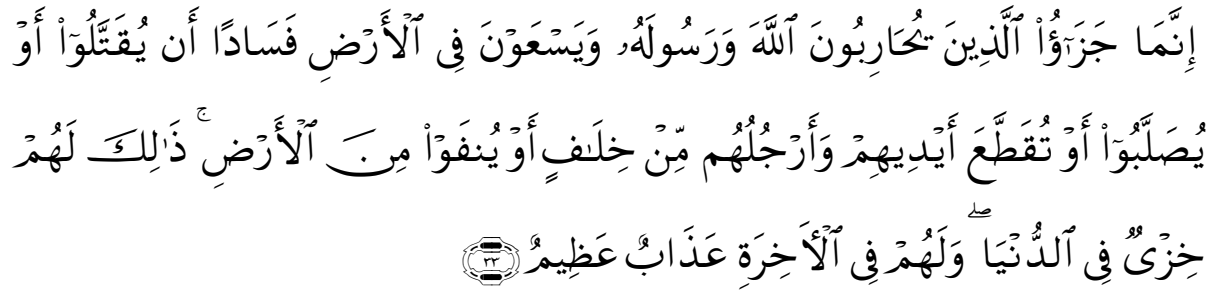

Sesungguhnya pembalasan terhadap orang-orang yang memerangi Allah dan RasulNya dan membuat kerusakan di muka bumi, hanyalah mereka dibunuh atau disalib, atau dipotong tangan dan kaki mereka dengan bertimbal balik, atau dibuang dari negeri (tempat kediamannya). yang demikian itu (sebagai) suatu penghinaan untuk mereka didunia, dan di akhirat mereka beroleh siksaan yang besar

Penerapan sanksi yang berat berdasarkan ayat di atas, karena hirâbah merupakan tindakan perampasan harta kekayaan secara terang-terangan dengan menggunakan senjata dan kekerasan yang menimbulkan rasa takut dan tidak aman bagi masyarakat di berbagai tempat baik di desa maupun kota. Sementara korupsi senantiasa dilakukan dengan cara-cara halus, rapi bahkan cenderung didukung oleh hukum yang bersifat koruptif, namun bahaya yang ditimbulkannya begitu massif. 
Lebih jauh lagi, ada perbedaan mendasar antara pencurian dan perampokan sebagaimana dikatakan al-Sayyid Abu Bakr, bahwa pencuri dalam melakukan aksinya (mengambil harta) pasti dengan cara sembunyi-sembunyi, konsekuensinya jika kedapatan mencuri, pelakunya pasti akan lari, sedangkan perampokan mengambil harta secara nyata dan terang-terangan, serta siap melakukan aksi lebih (penganiayaan, bahkan membunuh) jika pemilik harta tidak mau menyerahkan hartanya. ${ }^{15}$ Unsur mendasar inilah yang cukup krusial untuk diperhatikan jika akan dikaitkan dengan korupsi.

Selain hal di atas, konsep yang juga mendekati dan mirip dengan perilaku korupsi dalam hukum Islam adalah penggelapan (ghulûl) dan penyuapan (risywah), dengan hukuman ta'zîrnya. Ghulûl dan korupsi merupakan upaya penggelapan harta yang berada di bawah kekuasaannya. Artinya, harta memang diserahkan kepadanya oleh pemilik harta sebagai sebuah amanah, maka jika dikemudian hari ia berkhianat dengan menggelapkan harta itu, dapat dituntut melalui mekanisme peradilan. Sedangkan risywah dan korupsi, keduanya memiliki hubungan yang simbiosis mutualisme, yaitu tujuan penerima suap adalah untuk memperkaya diri, sementara pemberi suap selalu berorientasi untuk mendapatkan kebijakan yang menguntungkan dirinya.

Dalam menjatuhkan hukuman $t a^{\prime} z \hat{\imath} r$, hakim diberi kebebasan untuk menentukan jenis hukuman apa yang sesuai bagi terpidana korupsi. Dengan catatan, hakim harus tetap memperhatikan ketentuan umum tentang pemberian sanksi dalam hukum Islam, yaitu:

1. Hukuman hanya ditimpakan kepada pelaku kejahatan

2. Adanya kesengajaan atau kesalahan fatal

3. Hukuman dijatuhkan jika kejahatan dapat dibuktikan secara meyakinkan.

4. Berhati-hati dalam menentukan hukuman jika masih ada keraguan dan bukti yang tidak memadai. ${ }^{16}$

Untuk itu, terdapat beberapa jenis hukuman $t a^{\prime} z \hat{\imath} r$ yang dapat dikenakan terhadap pelaku tindak pidana korupsi:

\footnotetext{
15 al-Sayyid Abu Bakr, I'ânah at-Thâlibîn, (Beirut: Dar al-Fikr, t.t), 102.

16 Tim Penulis Muhammadiyah dan Nahdlatul Ulama, Koruptor..., 34.
} 
1. Denda dua kali lipat dari harta yang dikorupsi beserta hukuman fisik. Rasulullah SAW pernah bersabda; "siapa saja yang mengambil barang orang lain (pen, korupsi), maka dia harus mengganti dua kali lipat dari nilai barang yang telah dia ambil dan dia harus diberi hukuman". (HR. Al-Nasa'i, kitab sariq, No. 4872). ${ }^{17}$

2. Pengasingan; hukuman ini dapat dimaknai luas, tidak saja menempatkan terpidana di suatu tempat terpencil yang jauh dari keramaian, tetapi juga bisa berupa menjauhkan terpidana dari pergaulan sosial, seperti pengucilan. Hal ini didasarkan pada sebuah peristiwa di mana Nabi pernah memberi hukuman kepada tiga orang sahabat yaitu Ka'ab bin Malik, Murarah bin Rabi'ah al-Amiri dan Hilal bin Umayyah alWaqifi, yang enggan untuk ikut dalam perang tabuk berupa hukuman pengucilan dengan mendiamkan mereka selama lima puluh hari. ${ }^{18}$

3. Pemecatan dari jabatan; Jabatan yang diemban oleh seseorang merupakan amanah dari rakyat. Maka tatkala didapatkan seorang pejabat yang mengkhianati amanah publik tersebut, sudah sepatutnya diganti dengan orang lain yang lebih profesional, jujur dan memiliki integritas tinggi. Allah SWT berfirman dalam Q.S al-Anfal (8): 27:

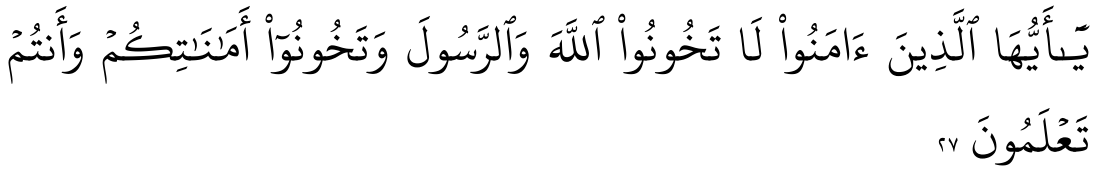

Hai orang-orang yang beriman, janganlah kamu mengkhianati Allah dan Rasul (Muhammad) dan (juga) janganlah kamu mengkhianati amanatamanat yang dipercayakan kepadamu, sedang kamu mengetahui.

4. Hukuman penjara; hukuman ini sebagai salah satu upaya represif sekaligus penjeraan terhadap terpidana korupsi. Ia ditempatkan di sebuah lembaga pemasyarakatan (lapas) khusus, dalam jangka waktu tertentu, dengan pengekangan atas kemerdekaan dan kebebasannya.

17 Ibid., 37.

18 Abi Zakariya Yahya bin Syarf An-Nawâwî, Riyâdl al-Shâlihîn, (Surabaya: Nurul Huda, t.t), 17-26. 
5. Hukuman mati; dalam kondisi tertentu jika mashlahat benarbenar menghendaki, dimungkinkan koruptor untuk dihukum mati. Misalnya korupsi dilakukan berulang-ulang (residivis), atau saat negara dalam keadaan krisis, atau korupsi atas anggaran kesehatan dan pendidikan. Untuk kadarnya (nishâb) dapat mempertimbangkan metodologi qiyas dalam kasus hukuman qishâsh, di mana seseorang dapat terhindar dari hukuman qishâsh jika ada pemaafan dan membayar denda berupa seratus ekor unta. Dengan demikian, koruptor yang menggelapkan uang rakyat seharga seratus ekor unta sudah dapat dikenakan hukuman mati. ${ }^{19}$

6. Pencabutan hak politik sebagai hukuman tambahan.

Penentuan bentuk hukuman bagi pelaku tindak pidana korupsi apakah dalam kategori hudîd atau tåzîr haruslah berdasarkan pertimbangan penegakan keadilan dengan melihat modus kejahatan dan dampak yang ditimbulkannya dalam masyarakat.

Di samping sanksi-sanksi sebagaimana diuraikan di atas, masih terdapat sanksi lain yang seyogyanya patut diperhatikan bagi seorang koruptor. Sanksi ini erat kaitannya dengan kehidupan seseorang setelah kematian. Para tokoh Nahdlatul Ulama' (NU) menyebutnya dengan sanksi akhirat. Sanksi ini antara lain:

1. Harta korupsi dapat menghalangi seseorang untuk masuk surga. Rasulullah bersabda: "Tidak akan masuk surga, daging yang tumbuh dari harta haram (as-suht)". (HR. al-Darimi)

2. Harta korupsi menjerumuskan pelakunya ke dalam neraka. Hal ini didasarkan pada sabda Nabi yang menyatakan bahwa "Tiap daging yang ditumbuhkan oleh al-suht, maka neraka lebih pantas baginya. Ditanyakan: wahai Rasulullah, apa al-suht itu? Rasulullah menjawab: risywah dalam hukum". (HR. al-Bukhârî)

3. Harta korupsi akan menjadi beban yang berat bagi pelakunya di hari kiamat. Rasulullah bersabda: “....demi Tuhan yang jiwa Muhammad berada dalam genggamannya. Tidak seorangpun dari kamu yang mengambil sebagian dari hadiah itu, kecuali pada hari kiamat dia akan memikul di lehernya seekor unta yang mengeluh atau sapi yang menguak atau kambing yang mengembik. Kemudian

\footnotetext{
19 Tim Penulis Muhammadiyah dan Nahdlatul Ulama, Koruptor..., 39.
} 
beliau mengangkat kedua tangannya sehingga kami dapat melihat warna putih ketiaknya. Lalu beliau bersabda: Ya Allah, bukankah (peringatan itu) telah aku sampaikan. Beliau mengulangi dua kali". (HR. Muslim). ${ }^{20}$

\section{Strategi Pemberantasan Korupsi dalam Perspektif Hukum Islam}

G.P. Hoefnagels pernah mengemukakan dalam bukunya "The Other Side of Criminology" sebagaimana dikutip oleh Barda Nawawi Arief, bahwa untuk menanggulangi suatu kejahatan, dapat dilakukan dengan menggunakan tiga hal berikut:

1. Dengan menerapkan hukum pidana (criminal law application),

2. Dengan pencegahan tanpa pidana (prevention without punishment), dan;

3. Dengan mempengaruhi pandangan masyarakat tentang kejahatan dan pemidanaan melalui mass media (influencing views of society on crime and punishment/mass media).21

Dengan demikian, secara garis besar, upaya untuk menanggulangi kejahatan, termasuk korupsi, dapat dilakukan dengan dua jalur, yaitu jalur penal (hukum pidana) dan jalur non-penal (diluar hukum pidana). Poin pertama di atas dapat dikategorikan sebagai upaya penanggulangan kejahatan melalui jalur penal, sedangkan poin kedua dan ketiga merupakan upaya penanggulangan kejahatan melalui jalur non-penal.

Menurut Barda Nawawi Arief, upaya penanggulangan kejahatan melalui jalur penal, lebih menitikberatkan pada sifat represif (penumpasan, penindasan atau pemberantasan) setelah kejahatan dilakukan. Adapun jalur non-penal lebih menitikberatkan pada sifat preventif (pencegahan, penangkalan atau pengendalian) sebelum kejahatan dilakukan. Di samping itu, ia juga menyatakan bahwa tindakan represif juga dapat berfungsi preventif dalam arti luas. ${ }^{22}$

Banyak kalangan beranggapan, bahwa upaya yang paling tepat untuk menanggulangi tindak pidana korupsi adalah dengan menjatuhkan hukuman pidana seberat-beratnya. Namun demikian,

\footnotetext{
20 Ibid., 139-140.

21 Barda Nawawi Arief, Bunga Rampai: Kebijakan Hukum Pidana, Perkembangan Penyusunan Konsep KUHP Baru, (Jakarta: Kencana, 2011), 45-46.

22 Ibid., 46.
} 
jika pemberian hukuman tersebut tidak disertai dengan integritas dan moral yang baik dari aparat penegak hukum, tetap saja akan membuat koruptor betah di balik jeruji besi. Hal ini terbukti pada 2009 ketika Satuan Tugas Pemberantasan Mafia Hukum melakukan sidak ke Rumah Tahanan (Rutan) Pondok Bambu, ditemukan sel mewah milik terpidana korupsi Artalyta Suryani. Kemudian tahun 2013 Wamenkumham Deny Indrayana juga melakukan hal sama di Lapas Sukamiskin (lapas khusus terpidana perkara korupsi) dan mendapati banyak sel mewah dengan fasilitas yg tidak sepantasnya diperoleh warga binaan. ${ }^{23}$

Sedangkan upaya non-penal dalam rangka preventif atas perilaku korupsi, dapat dilakukan dengan menggiatkan pengenalan dan pendidikan anti-korupsi sejak dini, berupaya untuk mengurus sendiri segala keperluan yang berhubungan dengan pelayanan publik, dan berani menyampaikan kepada masyarakat luas jika menemukan perilaku koruptif, baik melalui tulisan, kampanye atau gambar.

Lebih jauh, A.T. Rafique Rahman mengatakan terdapat 4 (empat) strategi yang dapat digunakan untuk melawan tindak pidana korupsi:

1. Strategi hesistant-environmental, yaitu; memerangi korupsi melalui gerakan-gerakan moral yang bersifat di luar kerangka legal-konstitusional. Bentuk gerakannya biasanya berupa program gerakan massa yang mengarahkan massa untuk menolak korupsi, sehingga pada akhirnya massa akan mengutuk perilaku korup tersebut. Selain itu, biasanya strateginya tidak terencana dan berbagai komponennya tidak terintegrasi dengan baik.

2. Strategi determined-environmental, yaitu; strategi gerakan moral yang terencana, tersistem, terintegrasi dan diimplementasikan dengan baik. Titik tekannya fokus pada upaya peningkatan kesadaran individu, kelompok atau masyarakat akan dampak buruk dari perilaku korupsi. biasanya strategi ini ditanamkan di dalam berbagai lembaga, seperti sekolah, kumpulan komunitas, keluarga dan sebagainya.

\footnotetext{
${ }^{23}$ Emerson Yuntho, "Penjara Pulau Khusus Koruptor," Jawa Pos, Opini, terbit pada
} hari Rabu, 19 Oktober 2016. 
3. Strategi hesistant-institutional, yaitu; strategi yang menekankan pada ukuran-ukuran kelembagaan. Misalnya menciptakan aturan hukum anti-korupsi, penyediaan layanan penampung aduan masyarakat sebagai salah satu upaya kerja sama dan partisipasi masyarakat dalam melawan korupsi, mempelopori kampanye anti-korupsi dalam berbagai kesempatan, dan lainlain.

4. Strategi determined-institutional, yaitu; strategi yang menitik beratkan pada ukuran-ukuran yang sistematis dan terkordinir untuk mendeteksi dan menghukum perilaku korup maupun mengurangi berbagai sumber penyebab korupsi. Dalam hal ini, penguasa dikontrol oleh masyarakat dalam merancang ukuran-ukuran prosedural, organisasi, hukum dan kelembagaan untuk benar-benar menghapus korupsi. Strategi ini meliputi; adanya lembaga anti-korupsi yang independen, sistem pemerintahan yang transparan, media massa yang bebas sehingga bisa menjadi media kontrol masyarakat dan sebagainya. ${ }^{24}$

Seluruh uraian di atas, selaras dengan semangat perjuangan umat Islam dalam memerangi korupsi. Ulama' NU misalnya, berpendapat bahwa dakwah dan pendidikan anti-korupsi dapat menjadi senjata ampuh untuk menangkal korupsi yang telah membudaya. ${ }^{25}$ Dari sisi dakwah, spirit Islam melawan korupsi mesti diserukan dalam berbagai kesempatan, misalnya di tempat-tempat pengajian, majlis taklim, baik di lingkungan masyarakat umum maupun di lingkungan birokrat; BUMN, aparat penegak hukum, pemerintahan dan sebagainya.

Sementara dari sisi pendidikan, dalam konteks keluarga misalnya, pendidikan anti-korupsi bisa diwujudkan melalui pembiasaan untuk jujur dan terbuka dalam urusan keluarga, menghargai hak milik anggota keluarga yang lain, serta amanah dalam menjaga kepercayaan orang tua dengan sendirinya akan melatih sikap anggota keluarga untuk melawan sifat curang. Dalam konteks masyarakat, pendidikan anti-korupsi perlu didukung oleh

\footnotetext{
24 Sri Yuliani, "Korupsi Birokrasi: Faktor Penyebab dan Penanggulangannya”, Jurnal "DINAMIKA" Vol. 6 N0.1 Th.2006, 7-9.

25 Tim Penulis Muhammadiyah dan Nahdlatul Ulama, Koruptor..., 154-157.
} 
komponen-komponen lain yang lebih luas. Misalnya televisi, saat ini banyak kalangan, seperti ulama', pakar pendidikan dan budaya, menilai bahwa tayangan yang dimuat oleh televisi lebih banyak menampilkan pola hidup yang glamor, hedonis dan konsumeris, yang dicurigai sebagai salah satu sebab maraknya praktik korupsi di negeri ini.

Selain kedua hal di atas (dakwah dan pendidikan antikorupsi), masyarakat perlu melakukan tindakan-tindakan yang berfungsi sebagai hukuman psikologis terhadap para koruptor agar mereka tidak bisa hidup nyaman. Tindakan tersebut dapat berupa menutup kesempatan bagi para koruptor untuk memiliki peran-peran tertentu dalam kehidupan sosial, tidak lagi menghormatinya, tidak lagi bergaul dengannya bahkan mengisolasi dan mengucilkan mereka dalam pergaulan sehari-hari. ${ }^{26}$

Lebih ekstrem lagi, NU menfatwakan larangan untuk menshalati jenazah seorang koruptor oleh pemuka agama. ${ }^{27}$ Tujuannya tidak lain agar setiap anggota masyarakat takut untuk melakukan korupsi (sebagai tindakan preventif) dan bagi yang telah melakukan korupsi agar jera (sebagai tindakan represif). Sistem hukum dan politik di negeri ini terkadang juga aneh, seseorang yang diduga melakukan tindak pidana korupsi atau bahkan yang sudah menjadi alumni pondok jeruji besi karena kasus korupsi, masih diberi akses kembali untuk mencalonkan diri sebagai pemegang kebijakan publik, baik sebagai calon walikota, bupati, DPR, dan sebagainya.

Memiliki pemimpin yang bersih dari segala macam bentuk perbuatan maksiat, seperti korupsi, merupakan salah satu syarat pokok dalam upaya memberantas korupsi. Dari pemimpin yang bersih ini diharapkan pejabat-pejabat di bawahnya dapat meneladani segala sifat pemimpin tersebut dan bisa menunjuk orang-orang yang tepat untuk menduduki jabatan-jabatan strategis, sehingga akses untuk melakukan korupsi dapat ditutup serapat mungkin.

Di antara sahabat Nabi yang tegas dalam memerangi korupsi adalah sahabat 'Umar Ibn Khattab. Ketika Umar akan mengangkat seorang pejabat di suatu wilayah, maka pejabat tersebut diwajibkan untuk menghitung kekayaannya sebelum serah terima jabatan.

\footnotetext{
26 Ibid., 159

27 Ibid., 138.
} 
Apabila kekayaannya bertambah (lebih dari gajinya), maka Umar akan memerintahkannya untuk memasukkannya ke dalam kas negara. Bahkan Umar melarang para pejabat untuk berbisnis, karena dengan jabatannya, dia akan menggunakan pengaruhnya untuk menguasai bisnis sehingga terjadi persaingan tidak sehat. ${ }^{28}$

Tentu, semua upaya di atas, tetap tidak boleh mengenyampingkan proses hukum melalui jalur penal bagi pelaku korupsi. Menindak para koruptor, mengadili dan memberikan sanksi pidana adalah sebuah keniscayaan. Akhirnya, dalam perang melawan korupsi, diperlukan kerja sama yang kuat berbagai elemen dan lembaga sosial masyarakat dengan komitmen besar untuk memberantas kejahatan tersebut hingga ke akar-akarnya.

\section{Penutup}

Dari semua paparan di muka, kita dapat mengenali bahwa dalam kajian hukum Islam, korupsi lebih dekat dengan ghulûl dan risywah dari pada dengan sariqah dan hirâbah. Korupsi dapat terjadi tidak hanya karena satu macam faktor, melainkan dari beragam faktor yang sangat rumit, karena dalam praktiknya biasanya melibatkan para ahli, tenaga profesional, bahkan cenderung mencari celah hukum. Maka sanksi yang seberat-beratnya sebagai bentuk penjeraan terhadap koruptor adalah sebuah keharusan. Mengingat dampak yang ditimbulkan dari perilaku korup sangatlah luas dan massif.

Di samping itu, agar setiap orang menghindari perilaku koruptif, secara garis besar, terdapat dua upaya yang perlu dilakukan, yaitu upaya represif melalui jalur penal dan upaya preventif melalui jalur non-penal. Jalur penal terhadap para koruptor dapat dilakukan dengan memberi sanksi pidana yang variatif sesuai dengan seberapa besar harta yang dikorupsi dan seberapa sering frekuensi korupsi dilakukan oleh orang tersebut. sementara jalur nonpenal dapat dilakukan dengan beragam aktivitas sosial yang mengarah pada tumbuhnya kesadaran masyarakat untuk membenci perilaku korup.

${ }^{28} \mathrm{Ibid}, 21$. 


\section{DAFTAR PUSTAKA}

Alatas, Syed Hussein, Sosiologi Korupsi: Sebuah Penjelajahan dengan Data Kontemporer, Jakarta: LP3ES, 1981.

Arief, Barda Nawawi, Bunga Rampai: Kebijakan Hukum Pidana, Perkembangan Penyusunan Konsep KUHP Baru, Jakarta: Kencana, 2011.

Atsir, Ibn Al-, al-Nihâyah fi Gharî̉ al-Hadîts wa al-Atsar, Jilid II.

Bakr, al-Sayyid Abu, I'ânat al-Thâlibîn, Beirut: Dar al-Fikr, t.t.

Danil, Elwi, Korupsi: Konsep, Tindak Pidana, dan Pemberantasannya, Jakarta: PT. RajaGrafindo Persada.

Hamzah, Jur. Andi, Pemberantasan Korupsi Melalui Hukum Pidana Nasional dan Internasional, Revisi ke-2, Jakarta: PT. RajaGrafindo Persada, 2006.

Tim Penulis Muhammadiyah dan Nahdlatul Ulama, Koruptor Itu Kafir, Jakarta: PT Mizan Publika, 2010.

Tim Penulis Buku Pendidikan Anti-Korupsi, Pendidikan Anti-Korupsi untuk Perguruan Tinggi, Jakarta: Kementerian Pendidikan dan Kebudayaan RI, 2011.

Poerwardarminta, W.J.S., Kamus Umum Bahasa Indonesia, Jakarta: Balai Pustaka, 1976.

Undang-Undang No. 20 Tahun 2001 tentang Pemberantasan Tindak Pidana Korupsi

Nawawî, Abi Zakariya Yahya bin Syarf al-, Riyâdl al-Shâlihîn, Surabaya: Nur al- Huda, t.t.

Yuntho, Emerson, Penjara Pulau Khusus Koruptor, Jawa Pos, Opini, terbit pada hari Rabu, 19 Oktober 2016.

Yuliani, Sri, "Korupsi Birokrasi: Faktor Penyebab dan Penanggulangannya", Jurnal "DINAMIKA" Vol. 6 N0.1 Th. 2006

Zuhaylî, Wahbah al-, al-Fiqh al-Islamî wa Adillatuh, Juz VI, Dar al-Fikr, Damaskus, 1984. 